\title{
Modelling Groundwater Recharge in a Semi-arid River Basin: A Retrospective Assessment
}

\author{
Julius M. Ndambuki, Charles Gyamfi, and Ramadhan W. Salim
}

\begin{abstract}
Groundwater constitutes an essential resource that augments surface water resources in meeting the water supply needs of man and the ecosystem. Most importantly in arid and semi-arid environments where rainfall patterns are erratic, groundwater resources are often the preferred source of water. This causes enormous pressure on the resource leading to diminishing groundwater resources. Land use changes also impact on groundwater resources through alterations in the hydrologic regime. It is imperative therefore to evaluate groundwater recharge dynamics under changing land uses to provide for a better resource planning and allocation. We present in this study, an investigation into groundwater recharge dynamics of the Olifants Basin, a water stressed basin in Southern Africa over the past decade with considerations to land use changes. Three land use change scenarios were developed to simulate the groundwater recharge of the basin within the Soil and Water Assessment Tool (SWAT) environment. The SWAT model was calibrated (1988-2001) and validated (2002-2013) with good model performance statistics; NSE, $\mathrm{R}^{2}$, PBIAS, RSR of 0.88 , $0.89,-11.49 \%, 0.34$ and $0.67,0.78,-20.69 \%, 0.57$ respectively for calibration and validation stages. Results indicate groundwater recharge declined by $30.3 \%(10.37 \mathrm{~mm})$ and $37.2 \%(12.71 \mathrm{~mm})$ during the periods $2000-2007$ and $2007-2013$ respectively. The decline in groundwater recharge was linked to the changes in urban $(9.2 \%)$, agriculture $(6.1 \%)$, rangelands $(-16.8 \%)$ during the period $2000-2007$ and urban $(1.3 \%)$, agricultural $(14 \%)$, rangelands $(-14.8 \%)$ during $2007-2013$. The SWAT model reveals it capabilities as a decision support tool (DST) in groundwater recharge assessment.
\end{abstract}

Keywords - Groundwater recharge, land use, Olifants Basin, SWAT.

\section{INTRODUCTION}

In arid and semi-arid regions of the world, groundwater serves as an essential alternative to surface water resources for water supply purposes. It plays a significant role in meeting the water demands of man and the ecosystem and is perceived as the panacea to the looming water scarcity scare [1]. This is reflective on its dependency for the supply of $43 \%$ of irrigation

Manuscript received Sept. 9, 2015. (Write the date on which you submitted your paper for review.) This work was supported by Tshwane University of Technology, Pretoria, South Africa.

C. Gyamfi is with the Tshwane University of Technology, Private Bag X680,Pretoria 0001 South Africa

J. M. Ndambuki is with the Tshwane University of Technology, Private Bag X680, Pretoria 0001 South Africa

R. W. Salim is with the Tshwane University of Technology, Private Bag X680, Pretoria 0001 South Africa water, $36 \%$ of potable water and $24 \%$ of industrial water globally [2]. At the current rate of abstraction, the sustainability of groundwater resources is questioned on the basis of its overexploitation [3] which is further worsened by land use/land cover (LULC) dynamics [4] coupled with the on-going climate change phenomenon. Land use /land cover changes (LULCCs) have widely been acknowledged to alter the hydrologic regime with consequent repercussions on the quantity of overland flow and indirectly affecting the quantum of groundwater recharge [5] - [8]. LULCCs are reported to have far reaching implications on the hydrologic cycle compared to the effects of climate change [9]. Increasing population is identified as a major driver to LULCCs causing a shift in natural vegetation towards more productive uses of land. This has triggered the conversion of the natural cover to arable lands with the focus of expanding the frontiers of dryland and irrigated agriculture in order to meet the ever increasing food demand [10], [11]. The conversion of natural vegetation to agriculture results in the modification of key vegetation parameters that influences recharge [12] and this has the tendency to irreversibly alter aquifer characteristics with replicative effects on groundwater availability [4].

Although there exist substantial evidence of LULCC impacts on the hydrologic cycle, most of these studies have focused on the atmospheric component of the hydrologic cycle leaving much to be desired on subsurface components of the hydrologic cycle and more in particular on groundwater resources [12]. In purview of this limitation, the impacts of LULCCs on groundwater resources need to be investigated with particular emphasis on groundwater recharge. Groundwater recharge defined as the portion of rainfall that reaches the saturated zone, either by direct contact in the riparian zone or by downward percolation through the unsaturated zone [13] is a vital part of the groundwater system that needs to be monitored to provide information of recharge dynamics with oriented focus on long term sustainability strategies for the management of groundwater resources.

The foregone discussions are not farfetched in the case of South Africa. In South Africa, the reliance on groundwater for agricultural, industrial and household water supply cannot be overemphasized [14], [15]. Perhaps, in many rural parts of South Africa groundwater remains the only reliable source of water supply [16]. This is particularly the case due to the semi-arid nature of the country predisposing it to erratic rainfall patterns with high inter-annual variations which tend to affect surface water availability. This has caused over dependency on groundwater resources resulting in their 
overexploitation. In the midst of this quagmire of overexploitation is also the incidence of LULCCs further altering the hydrologic regime and subsequently the recharge process [17]. Awakening to the call for sustainable management of water resources is the need for sustainable strategies to be devised not only for surface water resources but also for the inimitable groundwater resources. A critical approach in ensuring groundwater sustainability in the midst of changing land uses is to understand how LULCCs impact on groundwater recharge in order to provide the requisite knowledge to inform policy direction.

In this paper, we investigate the impacts of LULCC patterns on groundwater recharge through a modelling approach with a semi-distributed hydrologic model. The objective of the study was to investigate the feasibility of using a physically based distributed model to predict the changes that occur in groundwater recharge as a result of LULCCs and to quantify these changes. The approach is a simplistic way of cost effectively assessing groundwater recharge using readily available sources of information.

\section{Materials And Methods}

\section{A. Description of Study Area and Extent}

The Olifants River Basin is located in the northeastern part of South Africa with a total drainage surface area of $74,000 \mathrm{~km}^{2}$ (Fig.1). With a main stem of $770 \mathrm{~km}$, the Olifants River originates from Trichardt to the east of Johannesburg in the province of Gauteng and then flows in northeasterly direction through the provinces of Mpumalanga and Limpopo crossing the Mozambique border where it finally empties into the Massingir dam. Geographically, the basin lies on longitudes $28.3^{\circ} \mathrm{E}-31.9^{\circ} \mathrm{E}$ and latitudes $22.6^{\circ} \mathrm{S}-26.5^{\circ} \mathrm{S}$. For the purposes of this study, the Olifants Basin is herein referred to as the area extending from the upper Olifants to the location of gauge B7H015 (Fig. 1). The selection of the study area extent was solely informed by data availability on existing gauge stations that were required to calibrate and validate the model.

The Olifants River is drained by some major tributaries; on the right bank are Klein Olifant, Steelpoort and Blyde rivers with Wilge, Moses, Elands, Ga-Selati and Letaba on the left bank. Generally, the elevation of the basin ranges from 0 - 2328 meters above mean sea level (masl). Rainfall is erratic occurring during the months of October to April with appreciable spatio-temporal variability [18], [19]. The mean annual precipitation (MAP) is documented by [18] to be 664 $\mathrm{mm}$ with peaks in January. Temperatures range from $18{ }^{\circ} \mathrm{C}$ $34{ }^{\circ} \mathrm{C}$ in summer and $5^{\circ} \mathrm{C}-26^{\circ} \mathrm{C}$ in winter. The basin is characterized by five major soil types namely; cambic arenosols, chromic luvisols, chromic vertisols, orthic acrisols and rhodic ferralsols [20]. The population of the basin is estimated to be slightly over 5 million with a greater proportion being rural populace [21], [22].

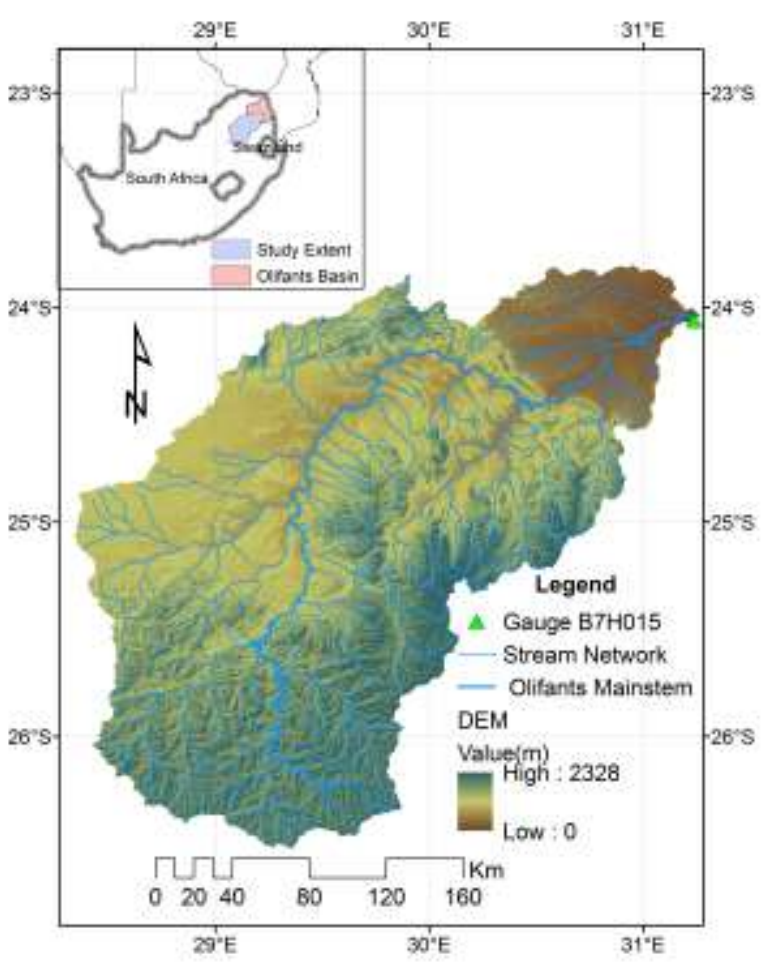

Fig. 1. Location and extent of study area showing gauge station.

\section{B. Hydrological Setting and Groundwater Occurrence}

The basin is characterized by four types of aquifers namely; weathered rock aquifer, fractured (structural) aquifer, dolomitic (karst) and the alluvial aquifers. Groundwater in the basin is mostly exploited from the dolomitic and weathered aquifer systems [15], [16]. The weathered aquifer has depth ranges of 5-12 $\mathrm{m} \mathrm{[23].} \mathrm{Groundwater} \mathrm{yields} \mathrm{from} \mathrm{the} \mathrm{weathered}$ aquifer are low with approximately 1 litres/second. Groundwater in fractured aquifers normally occurs in crevices. Fractured aquifers are encountered some few meters from the earth surface to a depth of about $30 \mathrm{~m}$ [23]. At depths below 30 $\mathrm{m}$, the crevices tend to close up due to the exertion of weight from the overlying formations. Yields in fractured aquifers are highly variable with high initial yields but tend to decline as a result of continuous abstraction.

Dolomitic aquifers in the Olifants Basin are mainly located in the western foothills of Drakensberg Mountains, Delmas and Marble Hall with yields ranging between 5 - 40 liters/second [16]. Dolomitic aquifers have the highest yields. Similar to dolomitic aquifers, alluvial aquifers have high yields and are located along watercourses with historic floodplains [16]. However for management purposes the Olifants Basin has been classified into three aquifer regions [24] to include major, minor and poor regions (Fig. 2). The major aquifer regions are associated with high yielding aquifer systems with good water quality whiles the minor aquifer regions are noted for moderately yielding aquifer systems. The poor regions have aquifers with low to negligible yielding aquifers. 


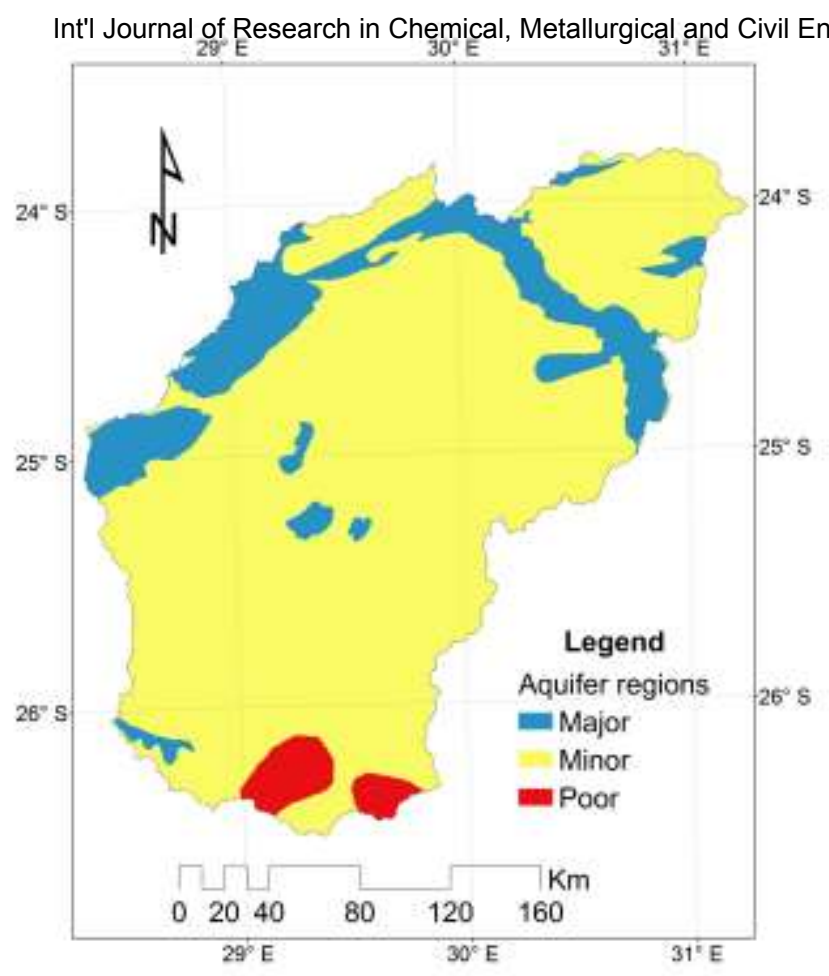

Fig. 2. Aquifer regions in the Olifants Basin.

\section{MODELLING APPROACH}

\section{A. Model Selection}

The assessment of LULCC impacts on groundwater recharge was carried out within the Soil and Water Assessment Tool (SWAT) environment. SWAT was developed jointly by United States Department of Agriculture-Agricultural Research Services (USDA-ARS) and Agricultural Experiment Station in Temple, Texas as a continuous, long-term, physically based distributed model suitable for the simulation of land use impacts on water, agricultural pollutants and sediment in large complex watersheds [25], [26]. Due to the model's versatility, it has been employed by many in diverse areas of land and water resources studies [27] - [30]. A comparison of SWAT with other hydrologic models revealed a higher success rate in SWAT [31] - [33]. The basic operational unit of the model is the hydrologic response unit (HRUs) which consist of an area of homogenous land use, management and soil characteristics. The HRUs are nested within sub-basins and hence simulations are aggregated at the HRUs and then unto the sub-basins. The model simulates the major components of the hydrologic cycle (surface runoff, evapotranspiration, percolation, lateral flow, return flow, transmission losses and ponds) base on the water balance equation represented in [26] as;

$$
\mathrm{SW}_{\mathrm{t}}=\mathrm{SW}_{\mathrm{o}}+\sum_{\mathrm{i}=1}^{\mathrm{t}}\left(\mathrm{R}_{\text {day }}-\mathrm{Q}_{\text {surf }}-\mathrm{E}_{\mathrm{a}}-\mathrm{W}_{\text {seep }}-\mathrm{Q}_{\mathrm{gw}}\right)
$$

Where; $\mathrm{SW}_{\mathrm{t}}$ is final soil water content $(\mathrm{mm}), \mathrm{SW}_{\mathrm{o}}$ is initial soil water content in day $\mathrm{i}(\mathrm{mm}), \mathrm{t}$ is time in days, $\mathrm{R}_{\text {day }}$ is amount of precipitation in day $\mathrm{i}(\mathrm{mm}), \mathrm{Q}_{\text {surf }}$ is amount of surface runoff in day $\mathrm{i}(\mathrm{mm}), \mathrm{E}_{\mathrm{a}}$ is amount of evapotranspiration in day $\mathrm{i}(\mathrm{mm}), \mathrm{W}_{\text {seep }}$ is amount of water entering the vadose zone from the soil profile in day $\mathrm{i}(\mathrm{mm})$ and $\mathrm{Q}_{\mathrm{gw}}$ is amount of return flow in day $\mathrm{i}(\mathrm{mm})$.

\section{B. Surface Runoff and Evapotranspiration Estimation}

Surface runoff $\left(\mathrm{Q}_{\text {surf }}\right)$ which refers to overland flow of excess water after infiltration and depression storages are fulfilled was estimated using a modification of the SCS-CN method [34]. The SCS-CN method is a function of antecedent moisture conditions, infiltration, soil type, land cover and other basin characteristics such as topography. The SCS-CN method as used in this study is defined as [34];

$$
\mathrm{Q}_{\text {surf }}=\left\{\frac{\left(\mathrm{R}_{\text {day }}-0.2 \mathrm{~S}\right)^{2}}{\left(\mathrm{R}_{\text {day }}+0.8 \mathrm{~S}\right)}, \mathrm{R}_{\text {day }}>0.2 \mathrm{~S}\right.
$$

Where; $\mathrm{Q}_{\text {surf }}$ is rainfall excess $(\mathrm{mm}), \mathrm{R}_{\text {day }}$ is the rainfall depth for the day $(\mathrm{mm}), \mathrm{S}$ is the retention parameter $(\mathrm{mm})$.

The retention parameter $\mathrm{S}$ is influenced by the changes that occur in land uses, soil water content and slopes and as result varies spatially across a watershed. The retention parameter was estimated as;

$$
\mathrm{S}=25.4\left(\frac{1000}{\mathrm{CN}}-10\right)
$$

Where; $\mathrm{S}$ is retention parameter $(\mathrm{mm})$ and $\mathrm{CN}$ is the curve number. $\mathrm{CN}$ is a function of soil permeability, antecedent soil conditions and land use. $\mathrm{CN}$ can be read from tables available in the literature by combining soil type and land use of a particular watershed.

Evapotranspiration which refers to water losses through evaporation and transpiration were accounted for using the Penman-Monteith method given as;

$$
\mathrm{ET}=\frac{0.408 \Delta\left(\mathrm{R}_{\mathrm{n}}-\mathrm{G}_{\mathrm{o}}\right)+\gamma \frac{900}{\mathrm{~T}+273} \mathrm{u}_{2}\left(\mathrm{e}_{\mathrm{s}}-\mathrm{e}_{\mathrm{a}}\right)}{\Delta+\gamma\left(1+0.34 \mathrm{u}_{2}\right)}
$$

Where; ET is the reference evapotranspiration $\left(\mathrm{mm} \mathrm{d}^{-1}\right), \Delta$ is the slope of the saturation vapour pressure temperature curve $\left(\mathrm{kPa}^{\circ} \mathrm{C}^{-1}\right), \mathrm{R}_{\mathrm{n}}$ is the net radiation $\left(\mathrm{MJ} \mathrm{m}^{-2} \mathrm{~d}^{-1}\right), \mathrm{G}_{\mathrm{o}}$ is the soil heat flux density $\left(\mathrm{MJ} \mathrm{m}^{-2} \mathrm{~d}^{-1}\right), \mathrm{e}_{\mathrm{s}}$ is the saturation vapour pressure $(\mathrm{kPa}), \mathrm{e}_{\mathrm{a}}$ is the actual vapour pressure $(\mathrm{kPa}), \gamma$ is the psychrometric constant $\left(\mathrm{kPa}^{\circ} \mathrm{C}^{-1}\right), \mathrm{e}_{\mathrm{s}}-\mathrm{e}_{\mathrm{a}}$ is saturation vapour pressure deficit $(\mathrm{kPa}), \mathrm{u}_{2}$ is wind speed $\left(\mathrm{ms}^{-1}\right)$, mean daily temperature $\left({ }^{\circ} \mathrm{C}\right)$.

\section{Groundwater Recharge Estimation}

Groundwater resources are replenished through the downward movement of water by percolation and further through the vadose zone to recharge aquifers. The amount of recharge that occurs is dependent on the hydraulic properties of existing geologic formations in the vadose zone and the water table [35]. In estimating the recharge, the exponential decay 
function proposed by [36] was used. The exponential function is formulated as;

$$
\mathrm{W}_{\text {rchrg,i }}=\left\{\mathrm{W}_{\text {seep }} \cdot\left(1-\exp \left[\frac{-1}{\delta_{\mathrm{gw}}}\right]\right)+\mathrm{W}_{\text {rchrg,i-1 }} \cdot \exp \left[\frac{-1}{\delta_{\mathrm{gw}}}\right]\right\}(5
$$

Where; $\mathrm{W}_{\text {rchrg,i }}$ is the amount of recharge entering the aquifers on day $\mathrm{i}(\mathrm{mm}), \delta_{\mathrm{gw}}$ is the delay time or drainage time of the overlying geologic formations (days), $\mathrm{W}_{\text {seep }}$ is the total amount of water exiting the bottom of the soil profile on day $i$ $(\mathrm{mm})$ and $\mathrm{W}_{\text {rchrg,i-1 }}$ is the amount of recharge entering the aquifers on day $\mathrm{i}-1(\mathrm{~mm})$.

\section{Input Datasets and Sources}

Required data for the model setup were digital elevation model (DEM), digital soil, data digital land use maps and climatic datasets (Fig. 3). The DEM was acquired from the global land cover facility database (GLCF) and is of spatial resolution $90 \mathrm{~m}$ x $90 \mathrm{~m}$ ( 3 arc sec). The DEM was used for basin discretization and extraction of geomorphologic characteristics such as width, depth, length of streams and slopes. Slopes discretization for the study area followed FAO classification scheme [37] to include; level to gently undulating $(<8 \%)$, rolling to hilly $(8-30 \%)$ and steeply dissected to mountainous $(>30 \%)$. Soil data and information on related soil properties were obtained from FAO soil map [20]. This data was augmented with information from field sampled soils. The extracted FAO soil data for the study area shows that the Olifants Basin is underlain by five major soil types namely; chromic luvisols (Lc) (38.81\%), cambic arenosols (Qc) $(33.03 \%)$, chromic vertisols (Vc) $(21.21 \%)$, orthic acrisols (Ao) $(5.77 \%)$ and rhodic ferralsols (Fr) (1.18\%).

LULC data for three epochs (2000, 2007 and 2013) was obtained through a supervised land use classification of Landsat 7 ETM+ images. The images are of spatial resolution $30 \mathrm{~m}$ and were acquired for Path/Row; 168/077, 169/077, 169/078, 170/077 and 170/078. The images were classified into five-level 1 classes based on the land cover and land use classification system developed by [38] for the interpretation of remote sensor data at various scales and resolutions. Climatic data consisted of daily rainfall, maximum and minimum temperatures and wind speed at thirteen weather stations acquired from the South African Weather Service (SAWS) for
1980 - 2013. The climatic dataset was augmented with data from the climate forecast system reanalysis (CFSR) database.

\section{E. Calibration and Validation Analysis}

The model was calibrated (01/01/1988 - 01/12/2001) and validated (01/01/2002 - 01/12/2013) using monthly stream flow data from gauge station $\mathrm{B} 7 \mathrm{H} 015$. The first 8 years prior to 1988 were used as warm up period to mitigate unknown initial conditions. Sensitive parameters to streamflow with their fitted values were adopted from [39]. The model performance was evaluated using four objective functions commonly used in the assessment of model performance [40] - [42].

- Coefficient of determination $\left(\mathrm{R}^{2}\right): \mathrm{R}^{2}$ is calculated as follows;

$$
\mathrm{R}^{2}=\left[\frac{\sum_{\mathrm{i}=1}^{\mathrm{n}}\left(\mathrm{O}_{\mathrm{i}}-\mathrm{S}_{\mathrm{i}}\right)\left(\mathrm{S}_{\mathrm{i}}-\overline{\mathrm{S}}\right)}{\left(\sum_{\mathrm{i}=1}^{\mathrm{n}}\left(\mathrm{O}_{\mathrm{i}}-\overline{\mathrm{O}}\right)^{2}\right)^{0.5}\left(\sum_{\mathrm{i}=1}^{\mathrm{n}}\left(\mathrm{S}_{\mathrm{i}}-\overline{\mathrm{S}}\right)^{2}\right)^{0.5}}\right]^{2}
$$

- Nash-Sutcliffe (NSE): NSE is formulated as;

$$
\mathrm{NSE}=1-\frac{\sum_{\mathrm{i}=1}^{\mathrm{n}}\left(\mathrm{O}_{\mathrm{i}}-\mathrm{S}_{\mathrm{i}}\right)^{2}}{\sum_{\mathrm{i}=1}^{\mathrm{n}}\left(\mathrm{O}_{\mathrm{i}}-\overline{\mathrm{O}}\right)^{2}}
$$

- RMSE - observations standard deviation ratio (RSR): $\mathrm{RSR}$ is calculated as;

$$
\text { RSR }=\frac{\text { RMSE }}{\text { STD }_{\text {obs }}}=\frac{\sqrt{\sum_{i=1}^{n}\left(O_{i}-S_{i}\right)^{2}}}{\sqrt{\sum_{i=1}^{n}\left(O_{i}-\bar{O}\right)^{2}}}
$$

- Percent Bias (PBIAS): PBIAS is calculated as shown;

$$
\text { PBIAS }=\frac{\sum_{\mathrm{i}=1}^{\mathrm{n}}\left(\mathrm{O}_{\mathrm{i}}-\mathrm{S}_{\mathrm{i}}\right)}{\sum_{\mathrm{i}=1}^{\mathrm{n}} \mathrm{O}_{\mathrm{i}}} \times 100 \%
$$

where; $\mathrm{O}_{\mathrm{i}}$ is observed variable, $\mathrm{S}_{\mathrm{i}}$ is simulated variable, $\overline{\mathrm{O}}$ is mean of observed variable, $\bar{S}$ is mean of simulated variable, $n$ is number of observations under consideration, RMSE is root mean square error, $\mathrm{STD}_{\mathrm{obs}}$ is standard deviation of observed variable. 


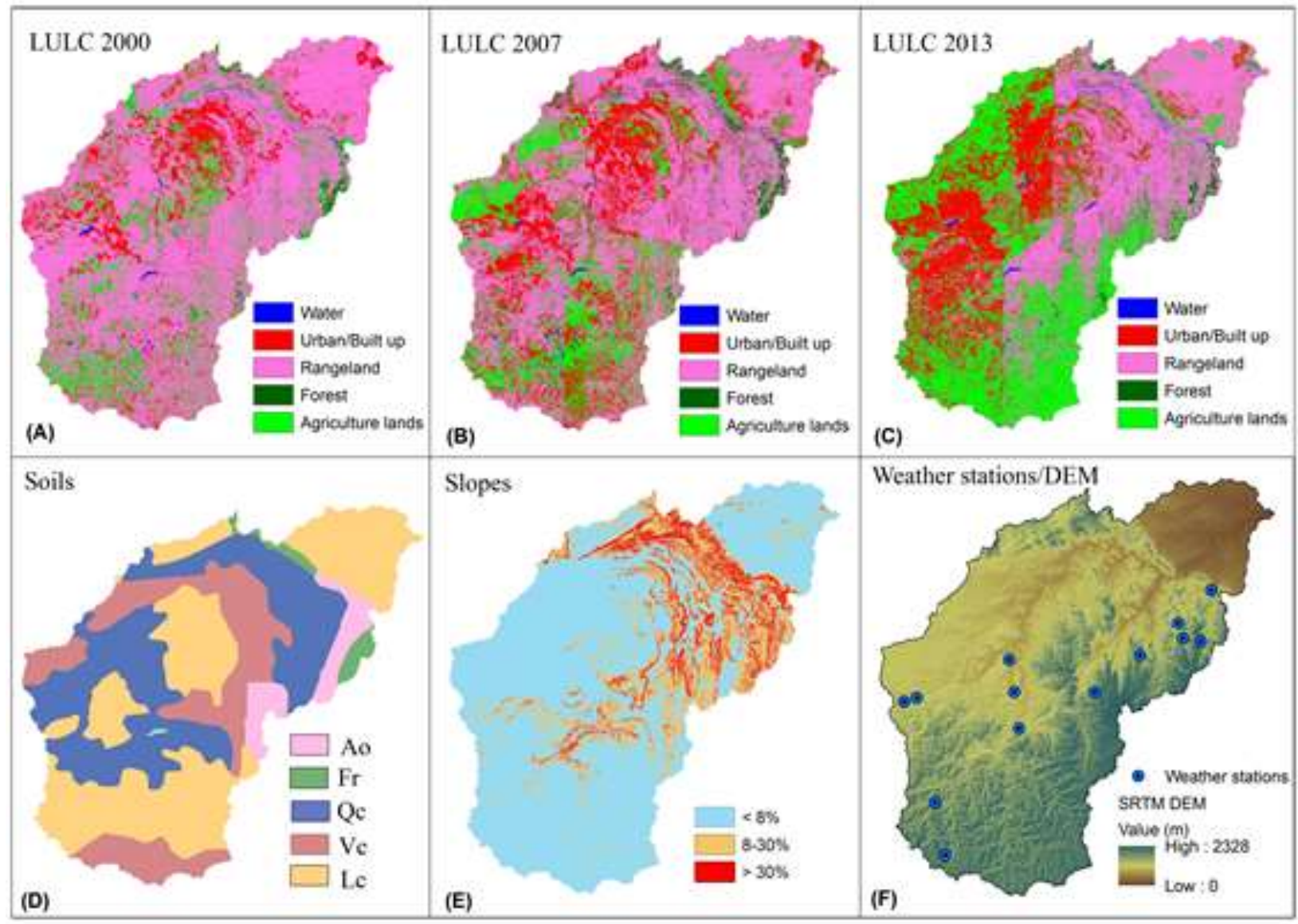

Fig. 3. Spatial model input parameters.

\section{A. Model Application and Statistical Analysis}

To assess the impacts of LULCCs on groundwater recharge of the Olifants Basin, the "fix-changing" method was used [6], [30], [43] - [45]. With this method, the calibrated model was run for each of the land use maps (2000, 2007 and 2013) whiles keeping constant the DEM, climatological parameters and soil data. Simulated results were further used to evaluate the impact of LULCCs on groundwater recharge. All statistical analyses were carried out in SPSS 20.0 and MS Excel 2010.

\section{RESUlts AND DisCUSSION}

\section{A. Land Use Change Detection}

Changes observed in LULC are shown in Fig. 4 for the period 2000 - 2013. All land use classes had undergone some degree of change. However, most significant changes were observed in three land use classes namely; urban areas, agricultural lands and rangelands. Urban and agricultural lands continually increased for all the years under review. Urban area extent of $13.2 \%$ in 2000 increased to $22.4 \%$ in 2007 . Urban areas gradually increased again from $22.4 \%$ in 2007 to $23.7 \%$ in 2013. Similarly, from 2000 to 2007, agricultural areas increased from $15.2 \%$ to $21.3 \%$. Further expansion in agriculture lands were observed, increasing from $21.3 \%$ in 2007 to $35.3 \%$ in 2013. Unlike agriculture and urban areas, rangeland continually decreased from $69.2 \%$ to $52.4 \%$ between the periods 2000 to 2007 .

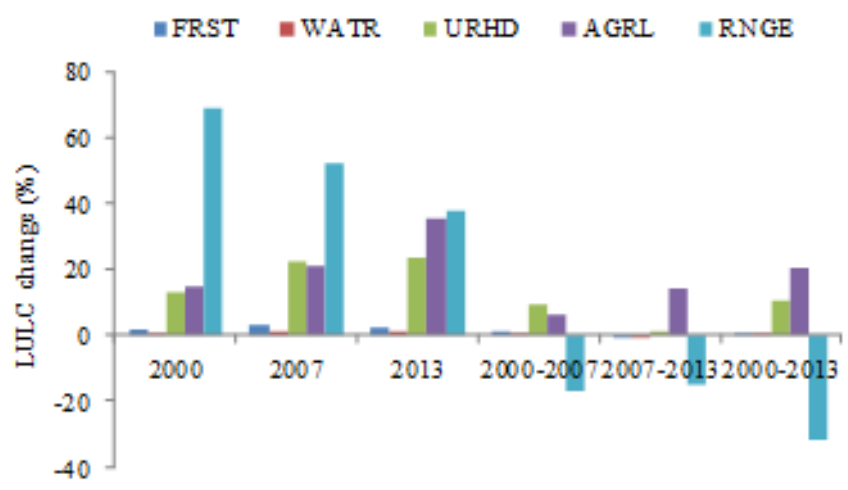

Fig. 4. Land use and land cover change for $2000-2013$. 
By the end of 2013, rangeland had decreased from 52.4\% in 2007 to $37.6 \%$ making it the land use type to have received most significant reduction for the period under review. The annual rate of change for forest, urban, agriculture and rangeland for $2000-2007$ were $10.1 \%, 9.9 \%, 5.8 \%$ and $-3.5 \%$ respectively.

Similarly during $2007-2013$, the annual rates of change were $-2.8 \%, 0.9 \%, 10.9 \%$ and $4.7 \%$ for forest, urban, agriculture and rangelands respectively.

\section{B. Calibration and Validation of Model}

The simulated and observed streamflow for the calibration period $(01 / 01 / 1988-01 / 12 / 2001)$ and the validation period $(01 / 01 / 2002$ - 01/12/2013) are compared in Fig. 5. The simulated streamflow matched well the observed data. The performance statistics are shown in Table I. Evidently from Table I, NSE and $\mathrm{R}^{2}$ values for both calibration and validation period are greater than 0.6 and the PBIAS values are in the range of $\pm 10 \%$ indicating a good model performance [41]. Although the model performance was satisfactory, system overestimations were witnessed as shown by the negative PBIAS values. Observed streamflow was overestimated by $11.49 \%$ and $20.69 \%$ for calibration and validation periods respectively.

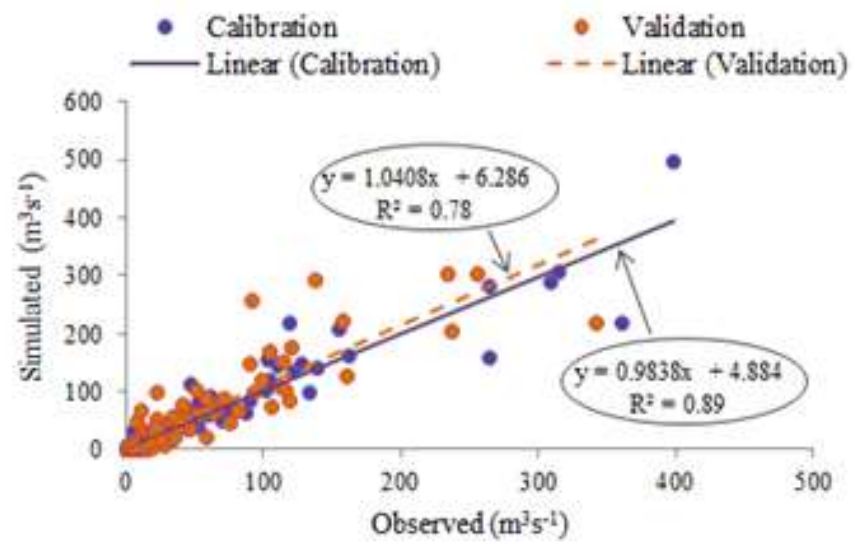

Fig. 5. Monthly simulated and observed discharge for calibration and validation periods

TABLE I: MODEL PERFORMANCE EVALUATION STATISTICS

\begin{tabular}{ccccc}
\multirow{2}{*}{ Model Stage } & \multicolumn{4}{c}{ Objective function } \\
\cline { 2 - 5 } & NSE & $\mathrm{R}^{2}$ & PBIAS (\%) & RSR \\
\hline Calibration(1988-2001) & 0.88 & 0.89 & -11.49 & 0.34 \\
& & & & \\
Validation (2002-2013) & 0.67 & 0.78 & -20.69 & 0.57 \\
\hline
\end{tabular}

\section{Impact of LULCC on Groundwater Recharge}

A trend of continuous groundwater decline was noticed for 2000 - 2013 (Fig. 6). From 2000 to 2007, the annual groundwater recharge decreased by $10.37 \mathrm{~mm}(30.3 \%)$ and the reduction was associated with LULCCs in urban (9.2\%), agriculture (6.1\%) and rangelands (-16.8\%) for the same period. A further decline in groundwater recharge of $12.71 \mathrm{~mm}$ (37.2\%) was observed in 2013 with concomitant changes in urban $(1.3 \%)$, agriculture (14\%) and rangelands $(-14.8 \%)$.
Similar decline in groundwater recharge have been reported by other studies [7], [30], [46]. The declining trend seen in the average groundwater recharge is attributed to increases in impervious areas due to urban and agriculture expansion which causes less soil infiltration. Groundwater resources within the basin are sourced for several activities including household water use, industrial uses, animal husbandry and irrigation [14], [15]. The decreasing trend in groundwater recharge can also be interpreted to mean the rate of abstraction exceeds that of recharge. The reduction in groundwater recharge as depicted by the model results is consistent with the findings of [3] where they asserted that groundwater is a preferred source of water over surface water due to the high inter-annual variations in precipitation which tend to affect surface water availability. This is particularly the case in semi-arid environments in Africa and so is the case of the Olifants Basin [47]. A further investigation revealed that groundwater recharge constituted 3 - 5\% (ratios of $0.03-0.05$ ) of basin-wide mean annual precipitation (Table II). This range has in the past been established by [48] to be $3-6 \%$.

TABLE II: POTENTIAL RATIOS OF BASIN HYDROLOGY SIMULATED ON THREE LULC SCENARIOS BASED ON HYDROLOGICAL YEAR (OCTOBER - SEPTEMBER).

\begin{tabular}{lllllll}
\hline \multirow{2}{*}{ LULC Scenario } & \multicolumn{7}{l}{ Water Balance Ratios* } \\
\cline { 2 - 7 } & $\mathrm{B} / \mathrm{TF}$ & $\mathrm{SR} / \mathrm{TF}$ & $\mathrm{SF} / \mathrm{P}$ & $\mathrm{PC} / \mathrm{P}$ & $\mathrm{DR} / \mathrm{P}$ & $\mathrm{ET} / \mathrm{P}$ \\
\hline 2000 & 0.26 & 0.74 & 0.07 & 0.1 & 0.05 & 0.78 \\
2007 & 0.25 & 0.75 & 0.09 & 0.05 & 0.04 & 0.82 \\
2013 & 0.24 & 0.76 & 0.09 & 0.08 & 0.03 & 0.80 \\
\hline *SF/P; & \multicolumn{7}{l}{ Streamflow/Precipitation, } & & $\mathrm{PC} / \mathrm{P} ;$
\end{tabular}

Perculation/Precipitation, DR/P; Deep Recharge/Precipitation, ET/P; Evapotranspiration/Precipitation, B/TF; Baseflow/Total flow, SR/TF; Surface runoff/Total flow.

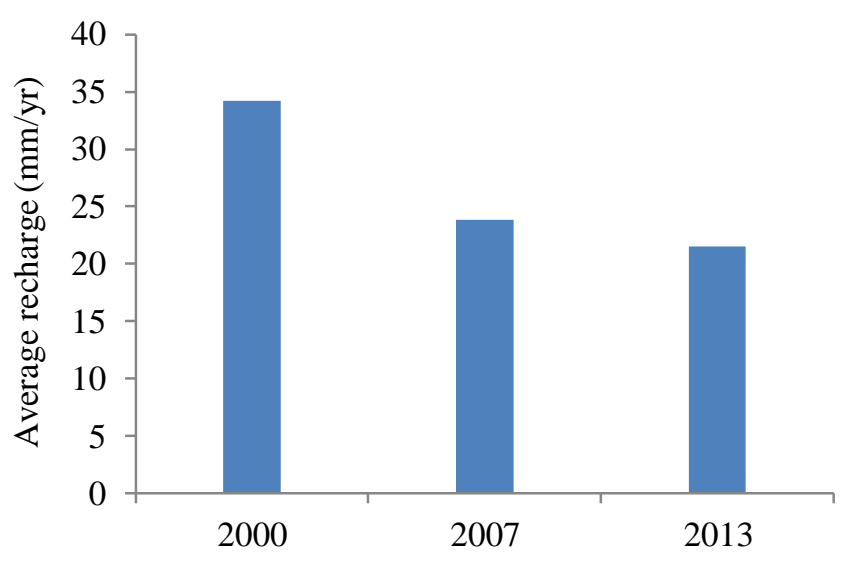

Fig. 6. Declining groundwater recharge for $2000-2013$.

\section{CONCLUSION}

The effects of LULCCs on groundwater recharge were investigated in this study using a physically based distributed hydrologic model. Results indicate that groundwater resources 
in the Olifants Basin are declining as a result of the continuous decline in recharge and also due to overexploitation issues. The declines in recharge were associated with the changes in major land uses within the Olifants Basin. The feasibility of using the SWAT distributed model with readily available data has proven worthwhile in the investigation of groundwater resources in terms of its recharge rate. It is recommended that further groundwater investigations should couple hydrologic models with field monitored groundwater data to optimize the application of such models.

\section{REFERENCES}

[1] N. S. Robins, and J. Fergusson. (February 2014). Groundwater scarcity and conflict - managing hotspots. Earth Persp. [online]. 1(6). pp. 1-9. Available: https://earth-perspectives.springeropen.com/articles/10.1186/2194-6434-16. doi:10.1186/2194-6434-1-6.

[2] P. Doll, H. Hoffmann-Dobrev, F. T. Portman, S. Siebert, A. Eicker, M. Rodell, G. Strassberg, and B. R. Scanlon. (September 2012). Impact of water withdrawals from groundwater and surface water on continental water storage variations. J. Geodyn. [online]. 59-60. pp.143-156. Available: http://www.sciencedirect.com/science/article/pii/S0264370711000597. doi:10.1016/j.jog.2011.05.001.

[3] R. C. Calow, and A. M. MacDonald. (March 2009). What will climate change mean for groundwater supply in Africa. ODI Background note. Overseas Development Institute, London.

[4] GWP. (2014). "The links between land use and groundwater - governance provisions and management strategies to secure a sustainable harvest. Available:

http://www.gwp.org/Global/ToolBox/Publications/Perspective\%20Papers/ perspective_paper_landuse_and_groundwater_no6_english.pdf.

[5] W. Nie, Y. Yuan, W. Kepner, M. S. Nash, M. Jackson, and C. Erickson. (September 2011). Assessing impacts of land use and land cover changes on hydrology for the upper San Pedro watershed. J. Hydrol. [online]. 407 (1-4). pp. 105-114. Available: http://www.sciencedirect.com/science/article/pii/S0022169411004549. doi.org/10.1016/j.jhydrol.2011.07.012.

[6] B.Yan, N. F. Fang, P. C. Zhang, and Z. H. Shi. (March 2013). Impacts of land use change on watershed streamflow and sediment yield: An assessment using hydrologic modelling and partial least squares regression. J. Hydrol. [online]. $\quad 484 . \quad$ pp. $26-37 . \quad$ Available: http://www.sciencedirect.com/science/article/pii/S0022169413000425 doi.org/10.1016/j.jhydrol.2013.01.008.

[7] T. J. Baker, and S. N. Miller. (April 2013). Using the soil and water assessment tool (SWAT) to assess land use impact on water resources in an East African watershed. J. Hydrol. [online]. 486. pp. 100-111. Available: http://www.sciencedirect.com/science/article/pii/S002216941300098X. doi.org/10.1016/j.jhydrol.2013.01.041.

[8] S. Wang, S. Kang, L. Zhang, and F. Li. (July 2008). Modelling hydrological response to different land use and climate change scenarios in the Zamu River basin of the northwest China. Hydrol. Process. [online]. 22 (14). pp. 2502-2510. Available: http://onlinelibrary.wiley.com. doi:10.1002/hyp.6846

[9] C. Vorosmarty, D. Lettenmaier, C. Leveque, M. Meybeck, C. Pahl-Wostl, J. Alcamo, W. Cosgrove, H. Grassl, H. Hoft, P. Kabat, F. Lansigan, R. Lawford, and R. Naiman. (November 2004). Humans transforming the global water system. Eos. [online]. 85(48). pp. 509-520.Available: https://ic.ucsc.edu/ wxcheng/envs168/Global_water_EOS.pdf.

[10] J. A. Foley, R. DeFries, G. P. Asner, C. Barford, G. Bonan, S. R. Carpenter, F. S. Chapin, M. T. Coe, G. C. Daily, H. K. Gibbs, J. H. Helkoski, T. Holloway, E. A. Howard, C. J. Kucharik, C. Monfreda, J. A. Partz, I. C. Prentice, N. Ramankutty, and P. K. Snyder. (July 2005). Global consequence of land use. Science. [online]. 309(5734). pp. 570-574. Available: http://science.sciencemag.org/content/309/5734/570. doi: 10.1126/science.1111772.

[11] H. C. J. Godfray, J. R. Beddington, I. R. Crute, L. Haddad, D. Lawrence, J. F. Muir, J. Pretty, S. Robinson, S. M. Thomas, and C. Toulmin. (February 2010). Food security: The challenge of feeding 9 Billion people. Science. [online]. 327(5967). pp. 812-818. Available: http://science.sciencemag.org/content/327/5967/812.full. doi. 10.1126/science.1185383.
[12] B. R. Scalon, R. C. Reedy, D. A. Stonestrom, D. E. Prudic, and K.F. Dennehy. (September 2005). Impact of land use and land cover change on groundwater recharge and quality in the southwestern US. Glob. Change Biol. [online]. 11. pp. 1577-1593. Available: http://www.beg.utexas.edu/staffinfo/Scanlon_pdf/ScanlonGCB05.pdf. doi: 10.1111/j.1365-2486.2005.01026.x.

[13] S. Adams, R. Titus, and Y. Xu. (2004). Groundwater recharge assessment of the basement aquifers of central Namaqualand. Report to Water Research Commission. WRC Report No. 1093/1/04. ISBN: 1-77005-214-3.

[14] De Lange, M., Merrey, D. J., Levite, H., and Svendsen, M. (2003). Water resources planning and management in the Olifants Basin of South Africa: past, present and future. IWMI, Pretoria, South Africa.

[15] DWA. (2011). Development of a reconciliation strategy for the Olifants River water supply system. Groundwater Options Report. Report No. PWMA 04/B50/00/8310/10, DWA, Pretoria, South Africa.

[16] J. J. Aston, (2000). Conceptual overview of the Olifants River Basin's groundwater, South Africa. Occasional paper. Colombo, Sri Lanka: International Water Management Institute (IWMI); Lynwood, South Africa: University of Pretoria, African Water Issues Research Unit (AWIRU). p17. Available: https://cgspace.cgiar.org/handle/10568/39178. Accessed (04-June-2016).

[17] D. N. Lerner, and B. Harris. (December 2009). The relationship between land use and groundwater resources and quality. Land Use Policy. [online]. 26(1). pp. S265-S273. Available: http://www.sciencedirect.com/science/article/pii/S0264837709001306. doi:10.1016/j.landusepol.2009.09.005

[18] C. Gyamfi, J. M. Ndambuki, and R. W. Salim (February 2016). A historical analysis of rainfall trend in the Olifants Basin in South Africa. Earth Sci. Res. [online]. 5(1). pp. 129-142. Available: http://www.ccsenet.org/journal/index.php/esr/article/view/56958. doi: 10.5539/esr.v5n1p129.

[19] M. P. McCartney, and R. Arranz. (2007). Evaluation of historic, current and future demand in the Olifants River catchment, South Africa. Research Report 118, International Water Management Institute, Colombo, Sri Lanka. IWMI.

[20] FAO. (2005). Digital soil map of the world and derived soil properties of the world. Food and Agricultural Organization of the United Nations. FAO, Rome.

[21] STATS SA. (2011). 2011 Population Census. Pretoria, South Africa.

[22] DWAF. (2002). Proposal for the establishment of a Catchment Management Agency for the Olifants water management area - Appendix C. Department of Water Affairs and Forestry, Pretoria.

[23] F. D. I. Hodgson, and R. M. Krantz. (1998). Groundwater quality deterioration in the Olifants River catchment above the Loskop dam with specialized investigations in the Witbank dam sub-Catchment. WRC Report No. 291/1/98. Water Research Commission, Pretoria, South Africa.

[24] R. Parson, and J. Conrad. (1998). Explanatory notes for the aquifer classification map of South Africa. WRC Report No. KV 116/98, ISBN 186845468

[25] J. G. Arnold, and N. Fohrer. (February 2005). SWAT2000: Current capabilities and research opportunities in applied watershed modeling. Hydrol. Process. [online]. 19(3). pp.563-572. Available: http://onlinelibrary.wiley.com/doi/10.1002/hyp.5611. doi: 10.1002/hyp.5611

[26] J. G. Arnold, R. S. Srinivasan, and J. R.Williams. (February 1998). Large area hydrologic modeling and assessment: Part 1. Model development. $J$. Am. Water Resour. Assoc. [online]. 34(1). pp. 73-89. Available: http://onlinelibrary.wiley.com/doi/10.1111/j.1752-1688.1998.tb05961.x/a bstract doi: 10.1111/j.1752-1688.1998.tb05961.x

[27] H. M.Yesuf, M. Assen, T. Alamirew, and A. M. Melesse. (April 2015). Modeling of sediment yield in Maybar gauged watershed using SWAT, northeast Ethiopia. Catena. [online]. 127. pp.191-205. Available: http://www.sciencedirect.com/science/article/pii/S0341816214003920 doi:10.1016/j.catena.2014.12.032

[28] T. Cai, Q. Li, M. Yu, G. Lu, L. Cheng, and X. Wei. (September 2012). Investigation into the impacts of land use change on sediment yield characteristics in the upper Huaihe River basin, China. Phys. Chem. Earth (B). [online]. 53-54. pp. 1-9. Available: http://www.sciencedirect.com/science/article/pii/S1474706511002439. doi: $10.1016 /$ j.pce.2011.08.023

[29] F. Githui, W. Gitau, F. Mutua, and W. Bauwens. (October 2009). Climate change impact on SWAT simulated streamflow in western Kenya. Int. J. Climatol. [online]. 29(12). pp. 1823-1834. Available: http://onlinelibrary.wiley.com/doi/10.1002/joc.1828. doi: $10.1002 /$ joc. 1828 
[30] G. Ghaffari, S. Keesstra, J. Ghodousi, H. Ahmadi. (March 2010). SWATsimulated hydrological impact of land use change in the Zanjanrood Basin, Northwest Iran. Hydrol. Process. [online]. 24(7). pp. 892-903. Available: http://onlinelibrary.wiley.com/doi/10.1002/hyp.7530.

doi: 10.1002/hyp.7530.

[31] D. K. Borah, and M. Bera. (2003). Watershed - scale hydrologic and nonpoint - source pollution models: review of mathematical bases. Trans. ASAE. [online]. 46(6). pp. 1553 - 1566. Available. http://webh2o.sws.uiuc.edu/iswsdocs/journals/TransASAE46-6-1553-156 6.pdf.

[32] M. W. Van Liew, and J. Garbrecht. (April 2003). Hydrologic simulation of the little washita river experimental watershed using SWAT. J. Am. Water Resour. Assoc. [online]. 39(2). pp. 413 - 426. Available: http://onlinelibrary.wiley.com/doi/10.1111/j.1752-1688.2003.tb04395.x/a bstract. doi: 10.1111/j.1752-1688.2003.tb04395.x

[33] M. S. Srinivasan, P. Gerald-Marchant, T. L. Veith, W. J. Gburek, and T. S. Steenhuis. (April 2005). Watershed-scale modeling of critical source areas of runoff generation and phosphorus transport. J. Am. Water Resour. Assoc. [online]. 41(2). pp. 361-375. Available: http://onlinelibrary.wiley.com/doi/10.1111/j.1752-1688.2005.tb03741.x. doi: 10.1111/j.1752-1688.2005.tb03741.x

[34] SCS. (1972). Section 4: Hydrology In National Engineering Handbook. SCS.

[35] S. L. Neitsch, J. G. Arnold, J. R. Kiniry, J. R. Williams, and K. W. King. (2009). Soil and water assessment tool. Theoretical documentation version 2009. Temple, TX: Grassland, soil and research service.

[36] C. Venetis. (1969). A study of the recession of unconfined aquifers. B. Int. Assoc. Sci. Hydrol. [online]. 14(4). pp. 119-125. Available: http://hydrologie.org/hsj/144/144011.pdf.

[37] FAO. 2003. The digital soil map of the world. Version 3.6. FAO, Rome.

[38] J. R. Anderson, E. E. Hardy, J. T. Roach, and W. E. Witmer (1976). A land use and land cover classification system for use with remote sensing data. USGS professional paper.964. pp. 138-145

[39] C. Gyamfi, J. M. Ndambuki, and R. W. Salim. (March 2016). Application of SWAT Model to the Olifants Basin: calibration, validation and uncertainty analysis. J. Water Resour. Prot. [online]. 8(3). pp. 397- 410. Available: http://www.scirp.org/journal/PaperInformation.aspx?PaperID=65180 doi.org/10.4236/jwarp.2016.83033.

[40] C. Santhi, J. G. Arnold, J. R. Williams, W. A. Dugas, and L. Hauck. (October 2001). Validation of the SWAT model on a large river basin with point and nonpoint sources. J. Am. Water Resour. Assoc. [online]. 37(5), pp.1169-1188.

Available: http://onlinelibrary.wiley.com/doi/10.1111/j.1752-1688.2001.tb03630.x. doi: 10.1111/j.1752-1688.2001.tb03630.x

[41] D. N. Moriasi, J. G. Arnold, M. W. Van Liew, R. L. Bingner, R. D. Harmel, and T. L.Veith. (2007). Model evaluation guidelines for systematic quantification of accuracy in Watershed Simulations. Trans. ASABE. 50(3). pp. 885-900. Available: http://citeseerx.ist.psu.edu/viewdoc/download?doi=10.1.1.532.2506\&rep= rep1\&type $=$ pdf.

[42] C. Oeurng, S. Sauvage, and J. Sanchez-Perez. (May 2011). Assessment of hydrology, sediment and particulate organic carbon yield in a large agricultural catchment using the SWAT model. J. Hydrol. [online]. 401(3-4). pp.145-153. Available: http://www.sciencedirect.com/science/article/pii/S0022169411001247

[43] G. Wang, J. Xia, and J. Chen. (July 2009). Quantification of the effects of climate variations and human activities on runoff by a monthly water balance model: a case study of the Chaobai River Basin in Northern China. Water Resour. Res. [online]. 45(7), pp. W00A11.Available:http://onlinelibrary.wiley.com/doi/10.1029/2007WR0 06768.doi: doi: 10.1029/2007WR006768.

[44] L. H. Tang, D. W. Yang, H. P. Hu, and B. Gao. (October 2011). Detecting the effect of land use change on streamflow, sediment and nutrient losses by distributed hydrological simulation. J. Hydrol. [online]. 409(1-2), 172-182. Available: http://www.sciencedirect.com/science/article/pii/S0022169411005415. doi: 10.1016/j.jhydrol.2011.08.015

[45] B. Lin, X. Chen, H. Yao, Y. Chen, M. Liu, L. Gao, and A. James (November 2015). Analysis of landuse change impacts on catchment runoff using different time indicators based on SWAT model. Ecol. Indicators. [online]. $58 . \quad$ pp. 55-63. Available:
http://www.sciencedirect.com/science/article/pii/S1470160X15002538.doi : 10.1016/j.ecolind.2015.05.031.

[46] M. P. Tripathi, R. K. Panda, and N. S. Raghuwanshi. (February 2005). Development of effective management plan for critical subwatersheds using SWAT model. Hydrol. Process. [online]. 19. pp. 809-826. Available: http://onlinelibrary.wiley.com/doi/10.1002/hyp.5618. 10.1002/hyp.5618.

[47] R. C. Calow, N. S. Robins, A. M. MacDonald, D. M. J. MacDonald, B. R. Gibbs, W. R. G. Orpen, P. Mtembezeka, A. J. Andrews and S. O. Appiah. (1997). Groundwater management in drought-prone areas of Africa. Int. J. Water Res. Dev. [online].13(2). pp. 241-262. Available: http://www.tandfonline.com/doi/abs/10.1080/07900629749863doi:10.108 0/07900629749863

[48] DWAF.(1991). Water resources planning of the Olifants River Basin Study of Development Potential and Management of the Water Resources. Pretoria, South Africa.

\section{BIOGRAPHY}

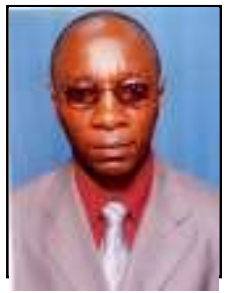

Julius M. Ndambuki is a Professor of Civil Engineering at the Tshwane University of Technology, Pretoria South Africa and the director for Scientists Networked for Outcomes from Water and Sanitation (SNOWS). His fields of research include groundwater modelling, stochastic optimization and multi-objective optimization. He is widely published and is an NRF rated researcher.

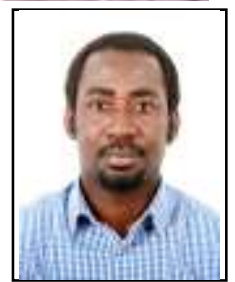

Charles Gyamfi had his undergraduate and masters degree in Civil Engineering from the Kwame Nkrumah University of Science and Technology, Kumasi-Ghana. Currently he is a doctoral research fellow and a part time lecturer at the Tshwane University of Technology, Pretoria, South Africa. His research interest centres on watershed hydrology, soil erosion modelling and the application of GIS/RS technologies in water resources management. He has co-authored a number of peer reviewed papers in both ISI and international journals. Mr. Gyamfi has also presented a number of research findings at international conferences.

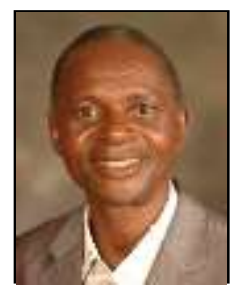

Ramadhan R. Salim holds a BSc (Hons), an MSc and a $\mathrm{PhD}$ in Civil Engineering and is an Associate Professor at Tshwane University of Technology, Pretoria, South Africa. His lecturing and professional experience stretches 24 years with specialization in the fields of Structural Engineering and curriculum development. His research interests include Self compacting concrete; Concrete as a carbon dioxide sink; Affordable / Low cost housing; Structural behaviour of biomaterials; Health Monitoring of Structures; Cellular light weight concrete elements; Laboratory simulation Fibre Reinforced Polymer in form of either Rebar, Strip or matrix in structural elements and Environmental waste management for environmental sustainability. 